\title{
Assessing the suitability of benthic foraminiferal morpho-groups to reconstruct paleomonsoon from Bay of Bengal
}

\author{
M Manasa*, Rajeev Saraswat and Rajiv Nigam \\ Micropaleontology Laboratory, Geological Oceanography Division, \\ CSIR - National Institute of Oceanography, Goa, India. \\ ${ }^{*}$ Corresponding author.e-mail: manumalenki@gmail.com
}

Temporal changes in benthic foraminiferal morpho-groups were suggested as an effective proxy to reconstruct past monsoon intensity from the Arabian Sea. Here, in order to test the applicability of temporal variation in morpho-groups to reconstruct past monsoon intensity from the Bay of Bengal, we have documented recent benthic foraminiferal distribution from the continental shelf region of the northwestern Bay of Bengal. Based on the external morphology, benthic foraminifera were categorized into rounded symmetrical (RSBF) and angular asymmetrical benthic foraminifera (AABF). Additionally, a few other dominant groups were also identified based on test composition (agglutinated, calcareous) and abundance (Asterorotalids and Nonions). The relative abundance of each group was compared with the ambient physico-chemical conditions, including dissolved oxygen, organic matter, salinity and temperature. We report that the RSBF are abundant in comparatively warm and well oxygenated waters of low salinity, suggesting a preference for high energy environment, whereas AABF dominate relatively cold, hypersaline deeper waters with low dissolved oxygen, indicating a low energy environment. The agglutinated foraminifera, Asterorotalids and Nonions dominate shallow water, low salinity regions, whereas the calcareous benthic foraminiferal abundance increases away from the riverine influx regions. Food availability, as estimated from organic carbon abundance in sediments, has comparatively less influence on faunal distribution in the northwestern Bay of Bengal, as compared to dissolved oxygen, temperature and salinity. We conclude that the factors associated with freshwater influx affect the distribution of benthic foraminiferal morpho-groups in the northwestern Bay of Bengal and thus it can be used to reconstruct past monsoon intensity from the Bay of Bengal.

\section{Introduction}

Temporal changes in benthic foraminiferal morphogroups, in cores collected from shallow marine regions influenced by riverine influx, were suggested as an efficient proxy to reconstruct past monsoon intensity (Nigam et al. 1992, 1995; Nigam and Khare 1999). The characteristic benthic foraminiferal assemblages in river dominated ocean margins are the result of the timing and extent of unique biogeochemical processes in both the water column as well as sediment. The unique biogeochemical processes in the ocean margins where rivers join the sea are influenced by the huge riverine influx of dissolved and particulate terrestrial matter (Hedges et al. 1997). The fluvial input is the

Keywords. Benthic foraminifera; Bay of Bengal; morpho-groups; Corg; agglutinated; calcareous foraminifera; paleomonsoon. 
major source of nutrients in such marginal environment and results in localized enhanced primary production (Lohrenz et al. 1997). This enhanced primary productivity may eventually increase the biomass and density of benthic organisms. The enhanced productivity can, however, also create hypoxic/anoxic conditions at the sediment-water interface, which can substantially reduce benthic faunal population (Kemp and Boynton 1992). Therefore, the terrigenous material brought by the rivers along with the freshwater and consequent change in energy conditions in front of the river mouths, leads to a peculiar sedimentary environment. Different colonization stages can be observed in these unique micro-environments wherein foraminifera respond with an opportunistic strategy (Fontanier et al. 2002, 2008; Mojtahid 2009; Goineau et al. 2011, 2012). The unique environmental conditions with a combination of enhanced productivity combined with low oxygen conditions in the riverine influx region thus result in reduced species diversity and predominance of a single species or a morpho-group (Severin 1983; Nigam et al. 1992, 2000; Nigam and Khare 1994, 1999; Jayaraju and Reddy 1997; Rana and Nigam 2009). Utilizing the presence of characteristic fauna in river-dominated marginal marine regions, the ratio of angular asymmetrical to rounded symmetrical benthic foraminifera, was suggested as a tool to reconstruct past monsoon intensity (Nigam et al. 1992). The method has the advantage of circumventing the need to identify all the benthic foraminifera up to species level, which is required when benthic foraminiferal species assemblages are used to reconstruct past monsoon.

The application of benthic foraminiferal morphogroups to reconstruct past monsoon from the Arabian Sea is, however, complicated by the presence of both seasonal coastal hypoxia and perennial intermediate water depth oxygen minimum zone (OMZ) (Naqvi et al. 2003). The high abundance of angular asymmetrical benthic foraminifera reported from such low dissolved oxygen zones, complicates the application of relative changes in angular asymmetrical benthic foraminifera to reconstruct past monsoon (Nigam et al. 2007, 2009; Nagy et al. 2009; Mazumder and Nigam 2014). Therefore, it is necessary to further test the relationship between riverine influx and relative abundance of benthic foraminiferal morpho-groups. The heavy freshwater influx along with huge sediment load from the Ganga-Brahmaputra-Mahanadi river system controls the physico-chemical parameters of the seawater in the northwestern Bay of Bengal, which ultimately affects the benthic fauna. Therefore, the northwestern Bay of Bengal is an ideal region to test the applicability of benthic foraminiferal morpho-groups to reconstruct past monsoon.
The previous work on foraminiferal distribution along the beaches and the estuaries adjoining the Bay of Bengal was initiated by Ghosh (1966) and followed by various researchers (Bhalla 1968; Ghosh and Bhattacharjee 1993; see Khare et al. 2007 for a comprehensive review). Foraminifera from the Bay of Bengal have also been used to reconstruct paleomonsoon (Cullen and Duplessy 1979; Cullen 1981; Duplessy 1982; Saraswat et al. 2005; Rana and Nigam 2009; Panchang and Nigam 2012). Even though, extensive studies to document benthic foraminiferal distribution have been carried out along the east coast of India, no detailed study has yet been carried out to document recent benthic foraminiferal distribution and their ecological preferences from continental shelf region off Ganga-Brahmaputra-Mahanadi region. Therefore, here, we document recent benthic foraminiferal distribution from the shelf region, off the GangaBrahmaputra-Mahanadi river system, one of the largest freshwater influx regions. We compare the benthic foraminiferal distribution with the ambient physico-chemical conditions, to understand and test the relationship between benthic foraminiferal morpho-groups and riverine influx. Other than the rounded symmetrical and angular asymmetrical benthic foraminifera, we have also studied the factors that control spatial distribution of total, calcareous, agglutinated and a few dominant benthic foraminiferal taxa in the northwestern Bay of Bengal.

\section{Environmental settings}

The northwestern Bay of Bengal receives immense volume of fresh water and sediment from three major river systems, viz., Ganga, Brahmaputra and Mahanadi. The total annual freshwater influx into the entire Bay is $2950 \mathrm{~km}^{3}$ (Sengupta et al. 2006), out of which Ganga and Brahmaputra rivers annually discharge $\sim 10^{12} \mathrm{~m}^{3}$ of fresh water into the Bay of Bengal at its northern end (Shetye 1993). More than $72 \%$ of this discharge occurs between June and September, the southwest monsoon period (Unger et al. 2003) and carries heavy sediment load $\left(1670 \times 10^{6} \mathrm{t} / \mathrm{yr}\right)$ with it. A major part of the riverine terrigenous input is deposited within the continental shelf region close to the river outlet, thus forming a delta, viz., Sunderbans (Milliman and Meade 1983). The delta is about $360 \mathrm{~km}$ wide, along the Bay of Bengal (Islam and Gnauck 2008). The fluvial input is the major source of nutrients to the Bay of Bengal. The annual supply of nutrients by Ganga and Brahmaputra rivers to the Bay of Bengal is $133 \times 10^{9} \mathrm{~mol} /$ year, which is $\sim 2 \%$ of the riverine input to the world ocean (Sarin et al. 1989). As a result of this heavy 
freshwater influx, salinity of the surface water is 3-7 psu lower in the Bay of Bengal throughout the year as compared to that in the Arabian Sea (Varkey et al. 1996). The heavy freshwater influx also causes strong water column stratification (Shetye et al. 1991; Shetye 1993). The Bay is considered to be a region of low biological productivity due to various reasons including narrow shelf, cloud cover during summer monsoon, turbidity resulting from sediment influx (Prasanna Kumar et al. 2010) and freshwater-induced water column stratification (Qasim 1977; Gomes et al. 2000). The sea surface salinity varies from 26 to $31 \mathrm{psu}$ in summer and between 27 and 31 psu in winter. The bottom water salinity ranges from 32.87 (at $28 \mathrm{~m}$ water depth) to $34.87 \mathrm{psu}$ (at $120 \mathrm{~m}$ water depth). The sea surface temperature (SST) in the northwestern Bay varies from $28.5^{\circ}$ to $29.0^{\circ} \mathrm{C}$ during summer monsoon and from $26^{\circ}$ to $28^{\circ} \mathrm{C}$ during the winter monsoon. The bottom temperature ranges from $18^{\circ}$ (at $120 \mathrm{~m}$ water depth) to $27.54^{\circ} \mathrm{C}$ (at $28 \mathrm{~m}$ water depth). The annual mean bottom water dissolved oxygen concentration varies from 0.43 (at $120 \mathrm{~m}$ water depth) to $3.9 \mathrm{ml} / \mathrm{l}$ (at $29 \mathrm{~m}$ water depth).
Latitudinal and seasonal variations are noted in the northwestern Bay of Bengal OMZ, which varies from $\sim 100$ to $800 \mathrm{~m}$ water depth (Wyrtki 1971; Naqvi et al. 1979; Rao et al. 1994).

\section{Materials and methodology}

The top $0-1 \mathrm{~cm}$ section of 22 box cores (SC 01SC 22), collected from the northwestern Bay of Bengal (BoB), from a depth of 28-120 m, during the 35th cruise of $R V$ Sindhu Sankalp (SSK 35), have been used (figure 1, table 1). The standard procedure was followed for the processing of sediment samples for foraminiferal studies. An appropriate amount $(5-10 \mathrm{~g})$ of sediment sample was collected in pre-weighed and properly labelled petri-dish. The petri-dish was covered by aluminum foil and frozen for 24 hours at $-30^{\circ} \mathrm{C}$. The frozen samples were transferred to freeze drier. The dried sediment samples were weighed and transferred to $1000 \mathrm{ml}$ beakers. The samples were soaked in distilled water. After $24 \mathrm{hr}$, the overlying water was decanted to remove fine colloidal suspended

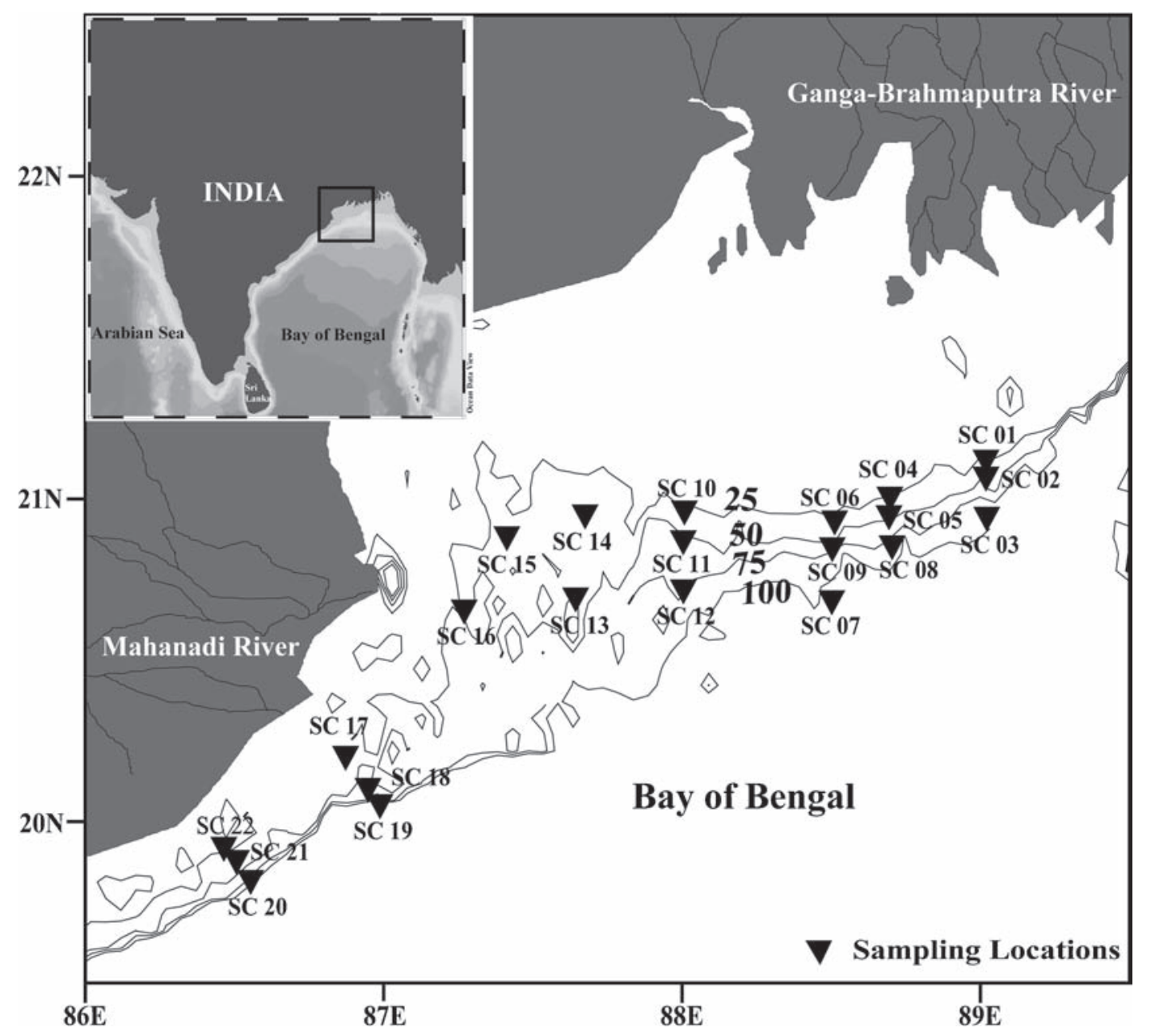

Figure 1. Map showing the sampling locations and bathymetry of the study area. 
Table 1. Details of the sample locations and environmental parameters in the study area.

\begin{tabular}{|c|c|c|c|c|c|c|c|c|c|c|c|c|}
\hline $\begin{array}{l}\text { Sl. } \\
\text { no. }\end{array}$ & Sample & $\begin{array}{l}\text { Longitude } \\
\qquad\left({ }^{\circ} \mathrm{E}\right)\end{array}$ & $\begin{array}{l}\text { Latitude } \\
\qquad\left({ }^{\circ} \mathrm{N}\right)\end{array}$ & $\begin{array}{c}\text { Depth } \\
(\mathrm{m})\end{array}$ & $\begin{array}{c}\text { Dissolved } \\
\text { Oxygen } \\
(\mathrm{ml} / \mathrm{l})\end{array}$ & $\begin{array}{c}\mathrm{T} \\
\text { (bottom) } \\
\left({ }^{\circ} \mathrm{C}\right)\end{array}$ & $\begin{array}{c}\text { Salinity } \\
\text { (bottom) } \\
(\mathrm{psu})\end{array}$ & $\begin{array}{l}\mathrm{TIC} \\
(\%)\end{array}$ & $\begin{array}{c}\text { Corg } \\
(\%)\end{array}$ & $\begin{array}{c}\text { Dry } \\
\text { sediment } \\
(\mathrm{g})\end{array}$ & $\begin{array}{c}\text { Coarse } \\
\text { fraction } \\
(\%)\end{array}$ & $\begin{array}{c}\text { Split CF } \\
\text { taken for } \\
\text { picking } \\
\quad(\mathrm{g})\end{array}$ \\
\hline 1 & SC-01 & 89.0186 & 21.1137 & 31.0 & 3.81 & 27.44 & 33.086 & 0.24 & 0.79 & 4.0838 & 2.35 & 0.0960 \\
\hline 2 & SC-02 & 89.0185 & 21.0612 & 49.0 & 3.44 & 26.10 & 33.986 & 0.31 & 0.75 & 4.7845 & 6.54 & 0.2524 \\
\hline 3 & SC-03 & 89.0212 & 20.9372 & 104.0 & 0.62 & 19.96 & 34.801 & 0.32 & 0.56 & 5.2131 & 0.25 & 0.0097 \\
\hline 4 & SC-04 & 88.6967 & 20.9990 & 29.0 & 3.87 & 27.51 & 33.023 & 0.31 & 0.66 & 7.3753 & 6.35 & 0.3512 \\
\hline 5 & SC-05 & 88.6935 & 20.9415 & 44.0 & 3.56 & 26.48 & 33.743 & 0.26 & 0.76 & 5.4017 & 7.85 & 0.2012 \\
\hline 6 & SC-06 & 88.5113 & 20.9255 & 35.5 & 3.73 & 27.11 & 33.366 & 0.29 & 0.68 & 8.1249 & 5.53 & 0.4293 \\
\hline 7 & SC-07 & 88.5018 & 20.6781 & 120.0 & 0.43 & 18.56 & 34.874 & 0.29 & 1.04 & 3.9665 & 0.59 & 0.0169 \\
\hline 8 & SC-08 & 88.7039 & 20.8484 & 94.0 & 1.29 & 21.04 & 34.739 & 0.21 & 0.88 & 5.2613 & 0.33 & 0.0119 \\
\hline 9 & SC-09 & 88.5035 & 20.8425 & 78.5 & 1.59 & 23.05 & 34.594 & 0.35 & 0.61 & 8.3943 & 1.53 & 0.1219 \\
\hline 10 & SC-10 & 88.0078 & 20.9563 & 31.0 & 3.81 & 27.44 & 33.086 & 0.43 & 0.48 & 8.8336 & 19.39 & 1.6938 \\
\hline 11 & SC-11 & 88.0040 & 20.8640 & 59.5 & 2.79 & 25.06 & 34.237 & 0.30 & 0.74 & 7.1454 & 1.95 & 0.0366 \\
\hline 12 & SC-12 & 88.0044 & 20.7117 & 83.0 & 1.37 & 22.44 & 34.636 & 1.25 & 0.16 & 5.7570 & 84.02 & 1.5043 \\
\hline 13 & SC-13 & 87.6433 & 20.6870 & 54.0 & 3.17 & 25.63 & 34.105 & 2.61 & 0.54 & 9.9958 & 43.79 & 0.0313 \\
\hline 14 & SC-14 & 87.6750 & 20.9441 & 42.0 & 3.62 & 26.63 & 33.630 & 0.72 & 0.19 & 13.732 & 85.34 & 3.9125 \\
\hline 15 & SC-15 & 87.4127 & 20.8765 & 36.0 & 3.72 & 27.07 & 33.379 & 0.42 & 0.74 & 7.6086 & 97.59 & 0.9222 \\
\hline 16 & SC-16 & 87.2698 & 20.6493 & 28.0 & 3.9 & 27.54 & 32.874 & 0.28 & 0.75 & 3.8805 & 6.30 & 0.0583 \\
\hline 17 & SC-17 & 86.8725 & 20.1959 & 34.0 & 3.75 & 27.22 & 33.278 & 0.43 & 0.62 & 9.9958 & 28.04 & 0.2684 \\
\hline 18 & SC-18 & 86.9475 & 20.0964 & 54.0 & 3.17 & 25.63 & 34.105 & 0.37 & 0.75 & 8.3690 & 3.76 & 0.0339 \\
\hline 19 & SC-19 & 86.9875 & 20.0461 & 96.0 & 0.81 & 20.78 & 34.751 & 0.21 & 1.14 & 4.9492 & 0.49 & 0.0184 \\
\hline 20 & SC-20 & 86.5541 & 19.8114 & 107.0 & 0.57 & 19.68 & 34.82 & 0.16 & 1.15 & 4.7757 & 1.17 & 0.0217 \\
\hline 21 & SC-21 & 86.5067 & 19.8733 & 47.0 & 3.49 & 26.25 & 33.933 & 0.15 & 0.87 & 6.2861 & 1.69 & 0.1218 \\
\hline 22 & SC-22 & 86.4645 & 19.9140 & 36.0 & 3.72 & 27.07 & 33.379 & 0.16 & 1.10 & 7.8100 & 2.66 & 0.2077 \\
\hline
\end{tabular}

organic matter. The beakers were re-filled with distilled water and the procedure was repeated until the overlying water was clear. The water from the beakers was finally decanted. The wet sediment samples were sieved through a $63 \mu \mathrm{m}$ mesh with very low water pressure to prevent foraminiferal test breakage. The $>63 \mu \mathrm{m}$ fraction (coarse fraction) was transferred to a glass beaker and dried overnight. The dried coarse fraction was weighed and stored in plastic vials.

Foraminifera were picked from a representative fraction taken out of the total coarse fraction by coning and quartering, by using Olympus SZX 12 stereozoom microscope. A minimum of 300 benthic foraminifera were picked from each sample. In case of lack of specimens, the total coarse fraction was used to pick all the available benthic foraminifera, which at times yielded less than 300 specimens. Based on the external morphology and test composition, benthic foraminifera were classified into several groups, viz., rounded symmetrical forms, angular asymmetrical forms, agglutinated, calcareous and a few abundant genera, namely Asterorotalids and Nonions. The morpho-group assemblage was analyzed by hierarchical agglomerative clustering on the square root transformed abundance data. Similarity percentage program (SIMPER) was then used to identify the morpho-group contributing to the similarity within the cluster and those mopho-groups responsible for dissimilarity between clusters. Indicator and discriminating groups were identified based on average similarity (dissimilarity)/standard deviation ratio and percentage similarity/dissimilarity contribution. A group with large similarity/dissimilarity percentage and small SD value will have large similarity (dissimilarity)/standard deviation ratio and hence are considered to be significant indicator/ discriminating group (Clarke and Warwick 2001). A reliable indicator group will have high abundance across the stations (high percentage similarity) and consistent abundance (high SIM/SD ratio), while a reliable discriminating group will have the highest abundance (highest percentage dissimilarity) in one cluster, but will be rare in the other cluster. The environmental variables (salinity, temperature and dissolved oxygen) for each sampling location are the annual means downloaded from the World Ocean Atlas 2009 by using the Ocean Data View website (Schlitzer 2015) (table 1). The total inorganic carbon (TIC) was measured by UIC CM 5014 coulometer after acidification of the sample with $1 \mathrm{~N} \mathrm{HCl}$ and measuring the $\mathrm{CO}_{2}$. The analytical accuracy is $\pm 0.43 \%$ and precision for total inorganic carbon analysis is $\pm 0.95 \%$. Total carbon (TC) was measured with a CE NCS 2500 elemental analyzer. 
In order to identify the relationship between various morpho-groups and environmental parameters, a canonical correspondence analysis (CCA) was performed. In ecological studies, multivariate statistical methods are widely used to characterize community structures and to quantify the relationship between communities and environmental parameters (Ramette 2007). By using multivariate analysis such as CCA, faunal data can be directly related to environmental parameters, thus allowing a more comprehensive analysis of foraminiferal ecology. The CCA is a direct gradient analysis, which generates axes that maximize the dispersion of the species scores and that are constrained to be a linear combination of the measured environmental variables (ter Braak 1986). The CCA analysis was carried out by using MVSP program, version 3.22 .

\section{Results}

\subsection{Coarse fraction $(>63 \mu \mathrm{m})$}

The coarse fraction $(>63 \mu \mathrm{m})$ percentage is high in the region in-between Ganga-Brahmaputra and Mahanadi rivers (figure 2a). The coarse fraction percentage decreases away from the river mouth, with increasing water depth in front of Mahanadi River. The lowest coarse fraction percentage is at station 3 (SC 03, at $104 \mathrm{~m}$ water depth) $(\sim 0.2 \%)$ while the highest abundance $(\sim 98 \%)$ is at the relatively shallow water station 15 (SC 15, $37 \mathrm{~m}$ water depth).

\subsection{Total foraminiferal number (TFN)}

Foraminiferal abundance varies from $\sim 25$ to $\sim 5100 / \mathrm{g}$ dry sediment (figure $2 \mathrm{~b}$ ). The $\mathrm{TFN}$ is
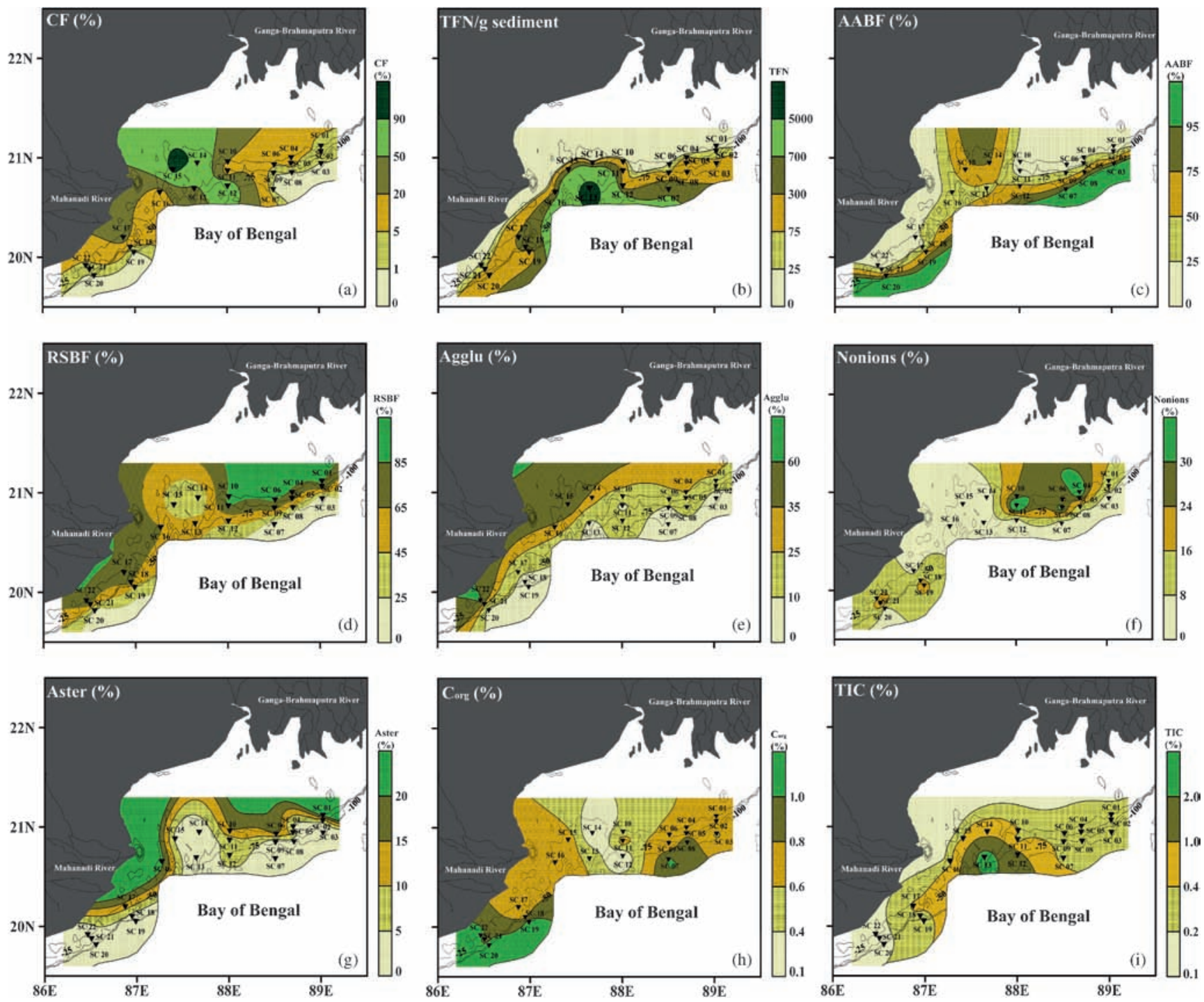

Figure 2. Distribution of (a) the coarse fraction, (b) total foraminiferal number (TFN), (c) angular asymmetrical benthic foraminifera $(\mathrm{AABF}),(\mathbf{d})$ rounded symmetrical benthic foraminifera (RSBF), (e) agglutinated foraminifera, (f) Nonions, (g) Asterorotalids, (h) organic carbon $\left(\mathrm{C}_{\mathrm{org}}\right)$, and (i) total inorganic carbon (TIC) in the continental shelf region of northwestern Bay of Bengal. 
highest at station 13 (SC 13, $54 \mathrm{~m}$ water depth) ( $\sim 5100 / \mathrm{g}$ sediment), located in-between the two river outlets, and the lowest at station 01 (SC 01, $31 \mathrm{~m}$ water depth), which is located in the northwestern part of the study area, right in front of the Ganga-Brahmaputra river mouth. Relict benthic foraminifera were found at two stations, SC 12 and SC 16 at a water depth of 83 and $28 \mathrm{~m}$, respectively. The relict benthic foraminifera are rare at both the stations and have not been included to calculate total foraminiferal abundance. The relict foraminifera, usually devoid of ornamentation, dull in luster and filled with secondary material, represent past low sea-stand and somehow escaped burial and remained exposed for a very long-time (Rana et al. 2007; Panchang et al. 2008).

\subsection{Angular asymmetrical benthic foraminifera}

Angular asymmetrical benthic foraminifera (AABF) are elongate uni-, bi- and tri-serial flattened rectilinear forms. The group included genera like Bolivina, Brizalina, Bulimina, Uvigerina, and Stainforthia. The abundance of angular asymmetrical foraminifera varies from $\sim 12$ to $\sim 96 \%$ (figure $2 \mathrm{c}$ ), with the highest abundance $(\sim 96 \%)$ observed at station SC 03 (104 m water depth). The AABF abundance is also high at stations SC 07 (at 120 m water depth), and SC 20 (107 m water depth) (table 2). The AABF abundance is very low in front of the rivers and increases towards the southern part of the study area, away from the riverine outlets with increasing water depth and decreasing dissolved oxygen level.

\subsection{Rounded symmetrical benthic foraminifera}

The abundance of rounded symmetrical benthic foraminifera (RSBF) is comparatively lower than that of angular asymmetrical benthic foraminifera. It varies from $\sim 4 \%$ to $\sim 88 \%$, with the highest abundance observed at station SC 10 (at $31 \mathrm{~m}$ water depth). The RSBF abundance is $>80 \%$ in SC 01 (at $31 \mathrm{~m}$ water depth), SC 02 (at $49 \mathrm{~m}$ water depth), SC 06 (at $35.5 \mathrm{~m}$ water depth), SC 11 (at $59.5 \mathrm{~m}$ water depth), and SC 22 (at $36 \mathrm{~m}$ water depth) (table 2). The RSBF abundance is very high in the shallow water regions in front of river outlets (figure $2 \mathrm{~d}$ ). These stations are in turn highly influenced by the freshwater discharge. The RSBF abundance decreases with an increase in distance from the coast or the distance from the river outlet with increasing water depth and decrease in dissolved oxygen level. This group included genera like Elphidium, Ammonia, Asterorotalia, Cancris, Nonion, Nonionella, and Lenticulina.

\subsection{Agglutinated and calcareous foraminifera}

A significant number of agglutinated foraminifera are also found in the northwestern BoB. Agglutinated benthic foraminiferal abundance varies from

Table 2. Relative abundances of morpho-groups in the northwestern BoB.

\begin{tabular}{|c|c|c|c|c|c|c|c|c|c|}
\hline $\begin{array}{l}\text { Sl. } \\
\text { no. }\end{array}$ & $\begin{array}{c}\text { Sample } \\
\text { no. }\end{array}$ & $\begin{array}{c}\text { Specimens } \\
\text { picked }\end{array}$ & $\begin{array}{c}\mathrm{TFN} / \mathrm{g} \\
\text { sediment }\end{array}$ & $\begin{array}{c}\mathrm{AABF} \\
(\%)\end{array}$ & $\begin{array}{c}\mathrm{RSBF} \\
(\%)\end{array}$ & $\begin{array}{c}\text { Asterorotalids } \\
(\%)\end{array}$ & $\begin{array}{c}\text { Nonions } \\
(\%)\end{array}$ & $\begin{array}{c}\text { Agglutinated } \\
\text { foraminifera (\%) }\end{array}$ & $\begin{array}{c}\text { Calcareous } \\
\text { foraminifera }(\%)\end{array}$ \\
\hline 1 & SC-01 & 104 & 25 & 13 & 87 & 24 & 11 & 23 & 77 \\
\hline 2 & SC-02 & 128 & 33 & 18 & 82 & 7 & 14 & 14 & 86 \\
\hline 3 & SC-03 & 401 & 102 & 96 & 4 & 0 & 2 & 2 & 98 \\
\hline 4 & SC-04 & 415 & 75 & 22 & 78 & 5 & 36 & 26 & 74 \\
\hline 5 & SC-05 & 412 & 161 & 22 & 78 & 10 & 28 & 16 & 84 \\
\hline 6 & SC-06 & 421 & 54 & 13 & 87 & 15 & 21 & 19 & 81 \\
\hline 7 & SC-07 & 1860 & 655 & 93 & 7 & 0 & 1 & 3 & 97 \\
\hline 8 & SC-08 & 392 & 107 & 69 & 31 & 0 & 10 & 17 & 83 \\
\hline 9 & SC-09 & 406 & 51 & 29 & 71 & 0 & 36 & 7 & 93 \\
\hline 10 & SC-10 & 1208 & 138 & 12 & 88 & 14 & 26 & 20 & 80 \\
\hline 11 & SC-11 & 379 & 201 & 13 & 87 & 7 & 46 & 4 & 96 \\
\hline 12 & SC-12 & 278 & 155 & 54 & 46 & 8 & 1 & 24 & 76 \\
\hline 13 & SC-13 & 370 & 5177 & 47 & 53 & 0 & 5 & 6 & 94 \\
\hline 14 & SC-14 & 393 & 86 & 75 & 25 & 1 & 1 & 31 & 69 \\
\hline 15 & SC-15 & 388 & 411 & 67 & 33 & 4 & 1 & 49 & 51 \\
\hline 16 & SC-16 & 313 & 338 & 34 & 66 & 22 & 6 & 32 & 68 \\
\hline 17 & SC-17 & 332 & 347 & 23 & 77 & 13 & 6 & 13 & 87 \\
\hline 18 & SC-18 & 385 & 427 & 27 & 73 & 3 & 17 & 5 & 95 \\
\hline 19 & SC-19 & 327 & 87 & 65 & 35 & 0 & 18 & 7 & 93 \\
\hline 20 & SC-20 & 379 & 204 & 88 & 12 & 0 & 5 & 4 & 96 \\
\hline 21 & SC-21 & 455 & 63 & 29 & 71 & 2 & 30 & 25 & 75 \\
\hline 22 & SC-22 & 329 & 42 & 20 & 80 & 0 & 13 & 63 & 37 \\
\hline
\end{tabular}


$\sim 2$ to $\sim 63 \%$ (figure 2e) with the highest (63\%) at location SC 22 (at $36 \mathrm{~m}$ water depth). A relatively high agglutinated foraminiferal abundance is also recorded at locations 14,15 and 16 (SC 14, SC 15 and SC 16). The abundance of the agglutinated foraminifera is more in the shallower part of the northwestern Bay of Bengal, near the river mouths. The calcareous foraminifera, on the other hand, show an opposite trend to that of agglutinated foraminifera. The abundance varies from $\sim 37 \%$ to $\sim 98 \%$, and is comparatively higher in the deeper locations.

\subsection{Nonions}

Nonions abundance varies from 1 to $46 \%$ (figure 2f). Nonions are abundant at location number 4, 9 and 21 (SC 04, water depth $29 \mathrm{~m}$; SC 09, water depth $78 \mathrm{~m}$; and SC 21, water depth $47 \mathrm{~m}$ ), right in front of the river mouths. The relative abundance of Nonions is relatively high in front of GangaBrahmaputra river mouth as compared to that in front of Mahanadi River.

\subsection{Asterorotalids}

Asterorotalids are found in 14 out of the total 22 samples. The abundance of Asterorotalids varies from 0 to $24 \%$ (figure $2 \mathrm{~g}$ ). The highest abundance of Asterorotalids is at location 01 (SC-01) (at 31 $\mathrm{m}$ water depth) (table 2), again right in front of the river mouth, while the abundance is very low in the deeper parts of the northwestern Bay of Bengal. Asterorotalids abundance is relatively high in front of Ganga-Brahmaputra river mouth as compared to that in front of Mahanadi River.
The relative abundance of Asterorotalids is low in the region in-between Ganga-Brahmaputra and Mahanadi river outlets. A few specimens of Asterorotalia in the northwestern Bay of Bengal have less than three or at times more spines. Ghosh (1966) also recorded Asterorotalia with one to four spines and considered them to be aberrant forms.

\subsection{Total organic carbon $\left(C_{\text {org }}\right)$ and total inorganic carbon (TIC)}

The $\% \mathrm{C}_{\text {org }}$ varies from 0.15 to $1.2 \%$ (dry weight) (figure $2 \mathrm{~h}$ ). The lower $\% \mathrm{C}_{\text {org }}$ is observed in relatively coarse grained sediments in-between the Ganga-Brahmaputra and Mahanadi river mouths (SC 12 and SC 14), while the high $\% \mathrm{C}_{\text {org }}$ is reported at relatively deeper locations dominated by fine-grained sediments (SC 07, SC 19, SC 20 and SC 22). TIC, includes both the in-situ biogenic carbonate as well as that brought from the land by the rivers. The TIC is very low in large part of the northwestern Bay of Bengal. The TIC in the northwestern Bay of Bengal varies from 0.1 to $2.6 \%$ (dry weight) (figure 2i) and is the highest at location 13 and 12. The lowest \% TIC is reported in front of the river mouths. As the larger fraction of TIC comprise of benthic foraminiferal calcareous shells, it is clear that low TIC indicates less abundance of calcareous benthic foraminifera. In the discussion section, TIC distribution is further compared and discussed with the total foraminiferal abundance.

\subsection{Cluster analysis}

The cluster analysis produced a dendrogram with four clusters at $75 \%$ similarity level (figure 3 ). The

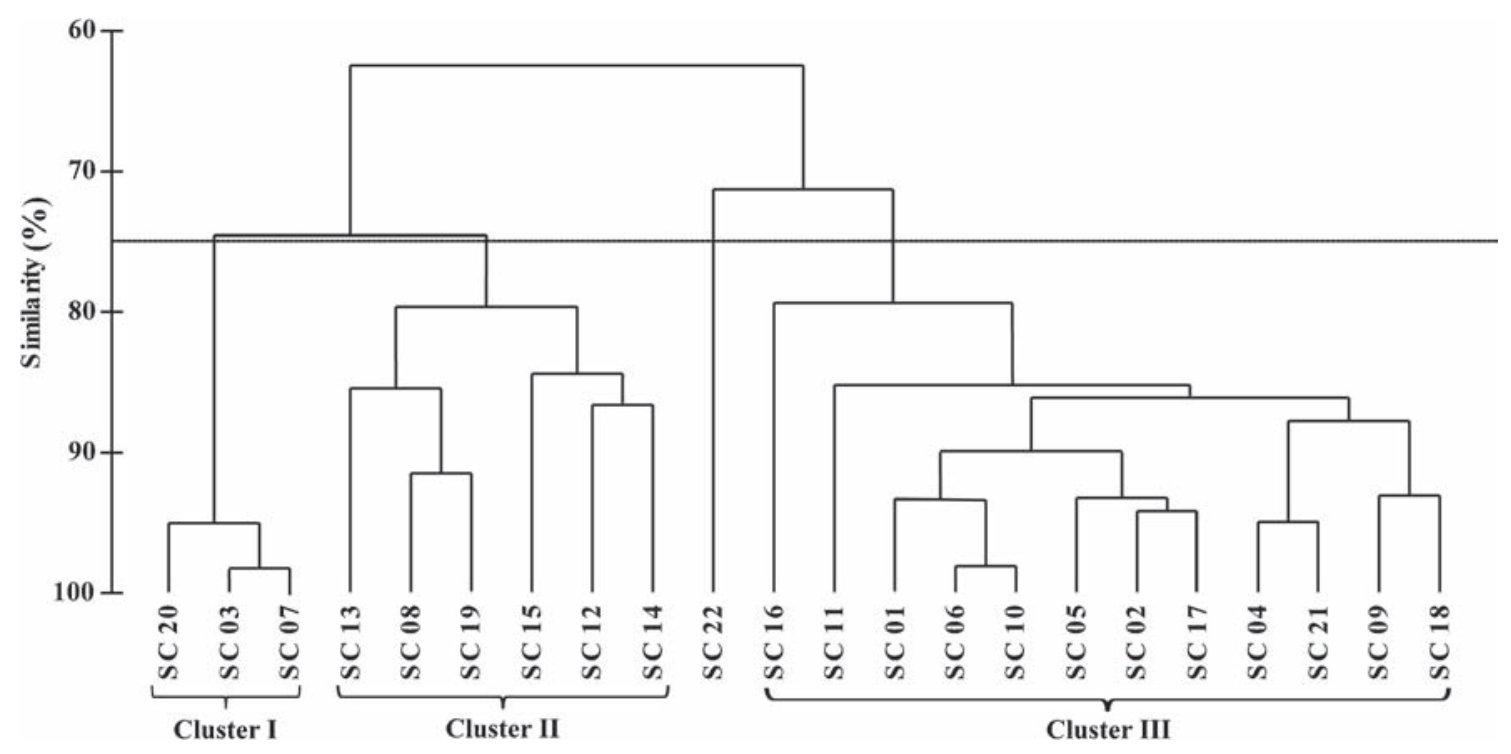

Figure 3. The cluster analysis dendrogram of sample stations. The arbitrary value of $75 \%$ similarity that represents a statistically significant cluster is marked by horizontal dark black line. 
Table 3. SIMPER analysis based on groups obtained from Bray-Curtis cluster.

\begin{tabular}{|c|c|c|c|c|c|}
\hline Species & Av. abund. & Av. sim. & $\mathrm{Sim} / \mathrm{SD}$ & Contrib. $\%$ & Cum. \% \\
\hline \multicolumn{6}{|l|}{ Cluster I } \\
\hline \multicolumn{6}{|c|}{ Average similarity: 86.58} \\
\hline Calcareous forms & 90.04 & 40.89 & 5.62 & 47.23 & 47.23 \\
\hline $\mathrm{AABF}$ & 87.95 & 40.63 & 9.88 & 46.93 & 94.16 \\
\hline \multicolumn{6}{|l|}{ Cluster II } \\
\hline \multicolumn{6}{|c|}{ Average similarity: 82.09} \\
\hline Calcareous forms & 79.26 & 33.32 & 4.35 & 40.59 & 40.59 \\
\hline $\mathrm{AABF}$ & 60.28 & 26.28 & 7.25 & 32.02 & 72.6 \\
\hline $\mathrm{RSBF}$ & 37.66 & 15.9 & 14.26 & 19.37 & 91.97 \\
\hline \multicolumn{6}{|l|}{ Cluster III } \\
\hline \multicolumn{6}{|c|}{ Average similarity: 86.49} \\
\hline Calcareous forms & 83.05 & 33.43 & 11.54 & 38.65 & 38.65 \\
\hline $\mathrm{RSBF}$ & 78.47 & 31.68 & 11.66 & 36.63 & 75.28 \\
\hline $\mathrm{AABF}$ & 21.26 & 7.28 & 3.06 & 8.42 & 83.7 \\
\hline Nonions & 23.09 & 6.58 & 1.76 & 7.6 & 91.3 \\
\hline
\end{tabular}

Cluster I consists of locations SC 20, SC 03 and SC 07 and is dominated by AABF and calcareous foraminifera. Cluster II consists of SC 13, SC 08, SC 19, SC 15, SC 12 and SC 14. Calcareous and $\mathrm{AABF}$ contributed to the similarity of this cluster as well, but the substantial abundance of RSBF distinguishes this cluster from Cluster I. The third cluster which includes stations SC 16, SC 11, SC 01, SC 02, SC 04, SC 05, SC 06, SC 08, SC 09, SC 10, SC 17 and SC 21, is although again dominated by calcareous foraminifera, also has large abundance of both the RSBF and AABF, along with Nonions, which are the better discriminators in Cluster III (table 3). Cluster IV comprising of only one station, viz., SC 22 is an outlier due to the highest abundance of agglutinated foraminifera $(63.22 \%)$.

\subsection{Correlation with environmental factors (CCA plot)}

A canonical correspondence analysis was performed to evaluate how well the environmental variables explain the distribution of identified morpho-groups. The length of the environmental arrow indicates the influence of the variable on the two axes. The significant environmental variables therefore tend to be represented by longer arrows than less important environmental variables which are represented by smaller arrow length (ter Braak 1986). The angle between the arrows and the axes is inversely proportional to the correlation between the environmental variable and the axes. On the biplot, the position of morpho-group is projected perpendicularly on to the environmental arrows to understand their weighed average optima along each environmental variable. The environmental conditions responsible for the development of a characteristic morpho-group/assemblage can be identified by this method. The first two axes explained $89 \%$ of the relationship between environment variable and foraminiferal distribution (figure 4). Temperature, dissolved oxygen and salinity were the most important environmental variables influencing the distribution as compared to the $\mathrm{CF} \%$ and $\% \mathrm{C}_{\text {org }}$. Total inorganic carbon although included in the CCA, is not depicted in the biplot as its length is less than one-tenth of the either axis (one of the optional criteria for displaying environmental variables), suggesting that it is not one of the important environmental variables influencing the benthic foraminiferal morpho-group distribution, in the study area. AABF showed a preference for higher salinity, lower temperature and low dissolved oxygen. Contrary to that, RSBF are positively correlated with both the temperature and dissolved oxygen and negatively correlated with salinity. Agglutinated foraminifera prefer warmer water, high dissolved oxygen and also higher percentage of coarse fraction but low salinity. Even though, the calcareous foraminifera showed a preference towards higher $\% \mathrm{C}_{\text {org }}$ and salinity, it is difficult to state the preference of this group with confidence, as it falls near the center of the biplot. Nonions are positively correlated with temperature, dissolved oxygen and negatively correlated with salinity. Asterorotalids prefer warmer temperature and high dissolved oxygen and low saline waters.

\section{Discussion}

The spatial distribution and population density of benthic foraminifera is controlled by numerous physico-chemical parameters such as organic matter 


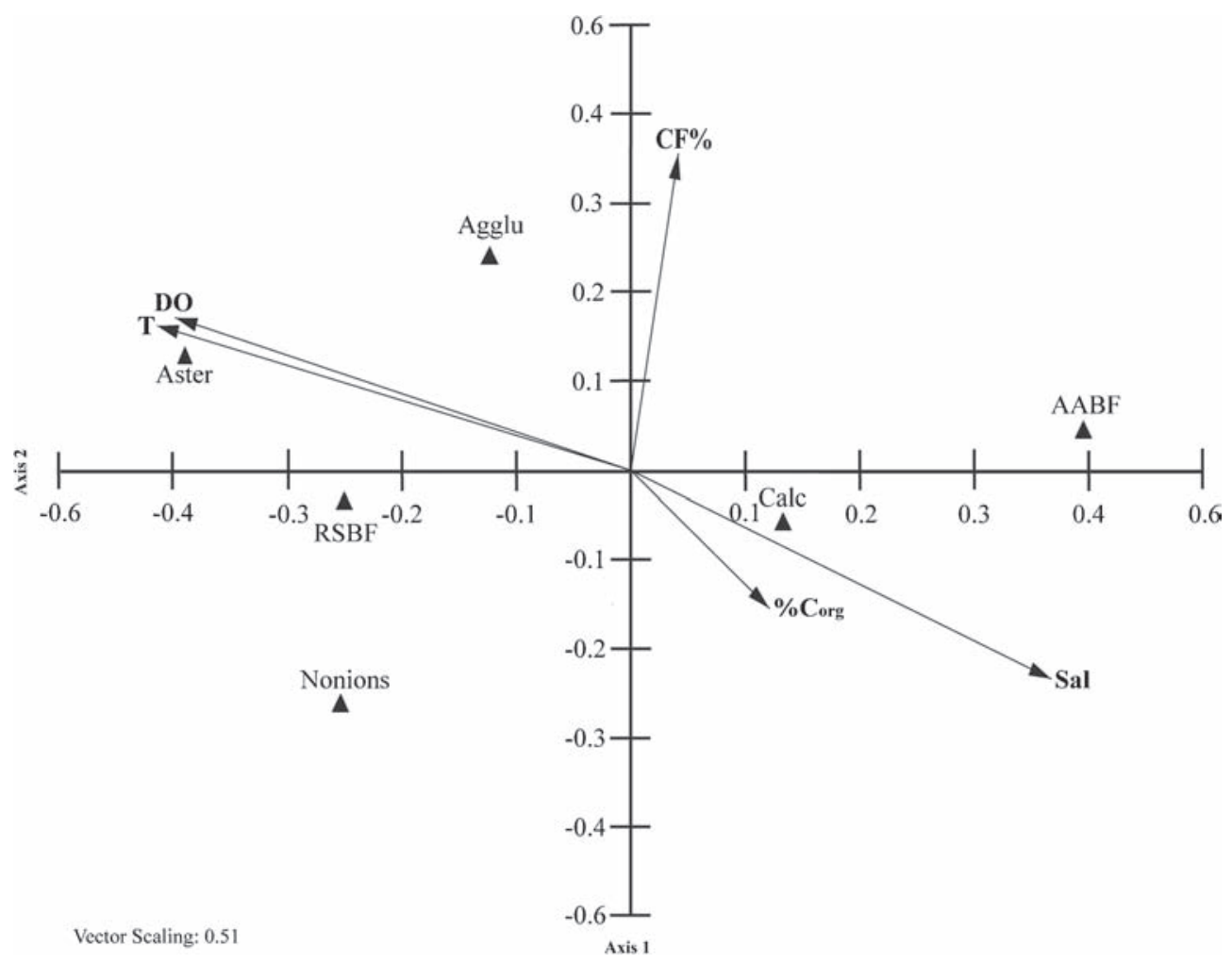

Figure 4. CCA biplot of benthic foraminiferal morpho-groups (inverted triangle) and environmental variables (arrow). Environmental abbreviations: $\mathrm{Sal}=$ Salinity, $\mathrm{CF} \%=$ Coarse fraction percentage, $\mathrm{T}=$ Temperature, $\mathrm{DO}=\mathrm{Dissolved} \mathrm{Oxy}-$ gen, $\% \mathrm{C}_{\mathrm{org}}=$ Organic Carbon. Morpho-group abbreviations: AABF=Angular Asymmetrical Benthic Foraminifera, Agglu=Agglutinated Foraminifera, Calc=Calcareous forms, RSBF=Rounded Symmetrical Benthic Foraminifera, Aster $=$ Asterorotalids, Nonion $=$ Nonions.

flux, oxygen availability, sea-water temperature, salinity, distance from the river mouth, extent of bioturbation, substrate, water depth and other related factors (Corliss and Fois 1990; Gooday 2003; Murray 2006; Jorissen et al. 2007). The relative effect of any of these factors, however, varies from location to location. In the northwestern Bay of Bengal, at comparable water depths, TFN is relatively higher in the region in-between the GangaBrahmaputra and Mahanadi influx regions as compared to the region right in front of these rivers. The increase in TFN away from the river mouth, suggests that the less turbid and low energy environment is conducive for foraminifera. As the distance from the river mouth increases, the salinity also increases, which is also responsible for the high foraminiferal abundance. The salinity in the study area depends on the freshwater discharge from the three river systems, viz., Ganga-BrahmaputraMahanadi. Foraminiferal abundance in the riverine influx dominated continental shelf region of the northwestern Bay of Bengal deviates from the widely accepted, generalized TROX model (Jorissen et al. 1995). We suggest that TROX model may not be able to explain benthic foraminiferal abundance in river-dominated very shallow continental shelf regions.
The oxygen deficiency is another factor, which controls benthic foraminiferal distribution in the northwestern Bay of Bengal. The locations marked by low dissolved oxygen have high $\mathrm{C}_{\text {org }}$ and increased abundance of fine-grained sediments. Although, such locations are in line of the river discharge they are towards the deeper side. The high benthic foraminiferal abundance at these locations can thus be explained with a combination of physico-chemical and biological factors. The freshwater influx from the river brings enormous quantity of nutrients, which enhances the productivity in the area and increases the food availability for foraminifera. A close relationship exists between abundance of benthic foraminifera and organic matter flux (Gooday 1993; Jorissen et al. 1992; Wahyudi and Minagawa 1997; Jorissen 1999). According to Setty and Nigam (1982), low organic carbon content is attributed to low input of organic matter, rapid decay, low sedimentation rate, arid conditions, sparse vegetation and lack of inflow from the surrounding terrains. All or a few of these factors can lead to low $\% \mathrm{C}_{\text {org }}$. Therefore, the high $\% \mathrm{C}_{\mathrm{org}}$ in front of the river mouths is attributed to better preservation in fine-grained sediments with high sedimentation rate. The highest $\% \mathrm{C}_{\text {org }}$ in the deeper part of the study area 
probably indicates high surface water productivity in less turbid regions (Prasanna Kumar et al. 2010). The high productivity with freshwater influx induced stratification, at deeper locations, results in low dissolved oxygen concentration (Sarma et al. 2013). Very high organic-matter flux in these areas induces severe oxygen depletion and only low oxygen tolerant taxa are able to survive in such low oxygen environment, resulting in increased abundance of a few opportunistic species (Sen Gupta and Machain-Castillo 1993; Jorissen et al. 1995; den Dulk et al. 1998; Jannink et al. 1998; Bernhard and Sen Gupta 1999; Kitazato et al. 2000; Schumacher et al. 2007; Glock et al. 2013; Caulle et al. 2013, 2015). Additionally, low dissolved oxygen is detrimental to large benthic organisms resulting in low bioturbation (Diaz and Rosenberg 2008; Sturdivant et al. 2012). The low bioturbation and increased amount of food will result in increased benthic foraminiferal population. The foraminiferal number is well correlated with TIC. However, the highest foraminiferal abundance is in a coarse fraction dominated station where TIC is also high. Here we would like to state that at few stations, benthic foraminiferal population is large enough to substantially influence the inorganic carbon content of the sediments.

From the plot (figure 2c), it is clear that the abundance of angular forms increases with distance from the river mouth as well as increase in organic carbon content and decreasing dissolved oxygen concentration. The CCA biplot confirms the high salinity (an indicator of distance from the riverine influx which brings freshwaters and thus lowers the salinity) and low dissolved oxygen preference of AABF (Buzas et al. 1993). Previously, relatively higher abundance of $\mathrm{AABF}$ has been reported from oxygen-depleted environments (Sen Gupta and Machain-Castillo 1993; Nigam et al. 2007; Schumacher et al. 2007; Nagy et al. 2009; Caulle et al. 2014). Additionally, we observe that the relative abundance of AABF also increases with decreasing sea-water temperature. But, the $\mathrm{AABF}$ abundance in the northwestern Bay of Bengal does not uniformly increase with increasing water depth, especially in the region falling inbetween the riverine influx area. Therefore, it is difficult to say whether the AABF abundance has a clear relationship with water depth. Therefore, based on the spatial distribution and the CCA plot, we conclude that the abundance of AABF is inversely related to the amount of freshwater influx in the northwestern Bay of Bengal. A huge amount of freshwater input from the rivers creates high energy environment in front of the river mouths, which adversely affects the abundance of angular asymmetrical foraminifera. A similar relationship between angular asymmetrical forms and the freshwater influx has also been reported from the northern Indian Ocean (Nigam 1993; Nigam and Khare 1994 (from west coast); Jayaraju and Reddy 1997; Rana and Nigam 2009 (from east coast)). Based on the CCA plot of the available data, we report that in the northwestern Bay of Bengal, low dissolved oxygen and sea-water temperature exert a dominant control on the relative abundance of $\mathrm{AABF}$, as compared to the freshwater influx.

As compared to the AABF, RSBF are abundant in the shallow water regions, highly influenced by the three river systems and hence, are the indicators of turbulent environment, as observed in deeper mixed layer depths in the northwestern Bay of Bengal (Chamarthi and Rao 2007). The riverine influx also decreases the sea-water salinity of the northwestern Bay of Bengal (Sengupta et al. 2006; Durand et al. 2011) and hence the abundance of RSBF in the shallow water regions suggests that such forms can survive in the low salinity environment. In the northwestern Bay of Bengal, the river discharge is largely due to monsoon precipitation. The fluctuations in riverine influx are related to the changes in monsoon intensity in the adjacent areas (Durand et al. 2011). Therefore, we suggest that changes in relative abundance of AABF and RSBF can be effectively used for the paleomonsoon reconstruction and freshwater intensity reconstruction from the core collected from the northwestern Bay of Bengal, as previously applied in the Arabian Sea and central Bay of Bengal (Nigam et al. 1992; Nigam and Khare 1994; Rana and Nigam 2009).

Based on the CCA plot, we report that agglutinated benthic foraminifera prefer low saline, relatively warmer and well-oxygenated waters. Additionally, the relative abundance of agglutinated foraminifera increases with an increase in abundance of coarser fraction. The previous studies from different parts of the world also suggest that the agglutinated foraminifera are more abundant in low saline, sandy substrate (Hayward and Hollis 1994; Murray et al. 2003). The increased relative abundance of agglutinated foraminifera in shallow water regions marked by low salinity is attributed to carbonate undersaturated waters as well as carbonate dissolution prevalent in these regions (Murray and Alve 2011). The studies on agglutinated foraminifera have suggested that in general, agglutinated foraminifera are less tolerant to low-oxygen conditions than calcareous foraminifera (Moodley et al. 1997; Neira et al. 2001; Gooday et al. 2009). Present study also confirms the strong influence of dissolved oxygen and warmer water on the relative abundance of agglutinated benthic foraminifera in front of the Ganga-BrahmaputraMahanadi river system (figure 4). Based on the CCA plot, we report that calcareous foraminifera prefer high $\% \mathrm{C}_{\text {org }}$ and salinity but it is difficult to 
state the preference of this group with confidence, as it falls near the center of the biplot. The spatial distribution, however, suggests that the calcareous foraminifera are more abundant in deeper regions away from the riverine influx. The higher salinity and relatively low energy environment, probably favours calcareous benthic foraminifera. Boltovskoy and Wright (1976) reported that the solubility of $\mathrm{CaCO}_{3}$ is proportional to salinity of the sea-water. Therefore, as the salinity decreases, the concentration of $\mathrm{CaCO}_{3}$ also decreases which in turn lowers the growth of foraminifera. Laboratory culture studies also confirm decreased growth and even reproduction in benthic foraminifera under hyposaline conditions (Nigam et al. 2006, 2008).

Nonions being round in shape, can survive in high energy environment as they are found in the inner shelf region (0-100 m water depth) (Murray 1991; Nigam et al. 1992; Nigam and Khare 1994). According to Murray (2006), the salinity preference of Nonions ranges from 32-35 psu. But in the northwestern Bay of Bengal, the abundance of Nonions is more, near the river mouth where salinity is comparatively low (34.237 psu, at $59.5 \mathrm{~m}$ water depth) while the dissolved oxygen is high. The abundance decreases as the distance from the river mouth increases. Duijnstee et al. (2004) reported that Nonionella turgida is negatively correlated with the bottom-water temperature and positively related to bottom water oxygenation. Contrary to this, Mojtahid et al. (2010) reported that maximum abundances of Nonian scaphum and Nonionella turgida found to occur in deep below in the sediment, below the limit of oxygen penetration. Gooday and Rathburn (1999) also stated that Nonionella have an ability to tolerate oxygen depletion resulting from the oxidation of organic carbon, in continental slope regions. According to Alve (2010), Nonionella iridea depends on seasonal supply of fresh phytodetritus to sustain its populations. Nonionella iridea have been recorded in sediments rich in organic carbon (Mackensen et al. 1985; Mackensen and Hald 1988). Based on the CCA plot, we suggest that the relative abundance of Nonions in the northwestern Bay of Bengal is strongly related with warmer, well oxygenated and low saline water.

Panchang and Nigam (2012) and Rao et al. (2013) studied the ecology of Asterorotalia trispinosa, in front of the Irrawaddy river delta and Muthupet Lagoon and concluded that Asterorotalia prefers low salinity and fine grained substrate. In the present study, based on CCA analysis, we report that Asterorotalids in the northwestern Bay of Bengal are affected not only by salinity, but also by temperature and dissolved oxygen concentration. Furthermore, CCA plot also showed that Asterorotalids prefer warmer, well oxygenated and low saline water. The surface distribution of Asterorotalids in the northern Bay of Bengal in front of rivers Ganga-Brahmaputra and Mahanadi also confirms that Asterorotalids prefer low salinity environment. But Murray (1991), found Asterorotalia in the less oxygenated waters of inner shelf regions of Andaman Sea.

\section{Conclusions}

Based on the distribution of benthic foraminifera in the surface sediments, collected from the northwestern Bay of Bengal in front of the GangaBrahmaputra-Mahanadi river systems, we report that TFN is relatively higher in the region inbetween the Ganga-Brahmaputra and Mahanadi influx regions as compared to the region right in front of these rivers, suggesting the influence of high energy, as well as $\% \mathrm{C}_{\text {org }}$ and only at few stations grain-size. The high abundance of RSBF indicates highly oxygenated warmer low saline water, which conforms with high energy environment, whereas the increased abundance of $\mathrm{AABF}$ indicates relatively cold and more saline water with low dissolved oxygen and higher $\% \mathrm{C}_{\text {org }}$ suggesting a preference for low energy environment. We further conclude that Asterorotalids and Nonions prefer low salinity, warmer water with high dissolved oxygen, whereas agglutinated benthic foraminifera can survive in low saline warm water with high dissolved oxygen as well as in coarse-grained sediments, again suggesting preference for high energy environment. Thus, the different benthic foraminiferal morpho-groups show different ecological preferences, with abundance being controlled by energy condition, salinity, temperature, dissolved oxygen and total organic carbon. The findings of this study will help us to better understand paleomonsoon intensities and freshwater input reconstructions by using benthic foraminifera.

\section{Acknowledgements}

We are thankful to the Director, National Institute of Oceanography, Goa for his kind permission to publish this work. We are thankful to the anonymous reviewers for their constructive comments and suggestions, that helped to significantly improve the earlier version of the manuscript. The financial support from the Ministry of Earth Sciences (MoES) (sanctioned to RN) and University Grant Commission (JRF/SRF to MM) are highly acknowledged. Dr C Prakash Babu and Dr V Ramaswamy are thanked for CN and Coulometer analysis. We thank Dr Sanitha K Sivadas, NIO, 
Goa and Dr Priya M D'Costa, Goa University, for their help in performing cluster and CCA analysis. We also thank Dr Nagender Nath for leading the cruise in which the samples were collected.

\section{References}

Alve E 2010 Benthic foraminiferal responses to absence of fresh phytodetritus: A two-year experiment; Mar. Micropaleontol. 76 67-75, doi: 10.1016/j.marmicro.2010. 05.003 .

Bernhard J M and Sen Gupta B 1999 Foraminifera of oxygen-depleted environments; In: Modern Foraminifera (ed.) Sen Gupta B K (Dordrecht: Kluwer Academic Press), pp. 201-216.

Bhalla S N 1968 Recent foraminifera from Vishakhapatnam beach sands and its relation to the known foramgeographical provinces in the Indian Ocean; Bull. Nat. Inst. Sci., India 38 376-392.

Boltovskoy E and Wright R 1976 Recent Foraminifera; The Hague, 8 233p.

Buzas M A, Culver S J and Jorissen F J 1993 A statistical evaluation of the microhabitats of living (stained) infaunal benthic foraminifera; Mar. Micropaleontol. 20 $311-320$.

Caulle C, Koho K A, Mojtahid M, Reichart G J and Jorissen F J 2013 Live foraminiferal faunas (Rose Bengal stained) from the northern Arabian Sea: Links with bottom-water oxygenation; Biogeosci. Discuss. 10 15257-15304, doi: 10.5194/bgd-10-15257-2013.

Caulle C, Koho K A, Mojtahid M, Reichart G J and Jorissen F J 2014 Live (Rose Bengal stained) foraminiferal faunas from the northern Arabian Sea: Faunal succession within and below the OMZ; Biogeosci. 11 1155-1175, doi: $10.5194 /$ bg-11-1155-2014.

Caulle C, Mojtahid M, Gooday A J, Jorissen F J and Kitazato H 2015 Living (Rose-Bengal stained) benthic foraminiferal faunas along a strong bottom-water oxygen gradient on the Indian margin (Arabian Sea); Biogeosci. 12 5005-5019, doi: 10.5194/bg-12-5005-2015.

Chamarthi S and Rao A D 2007 Effect of River Discharge on Bay of Bengal Circulation; OCEANS 2006 - Asia Pacific, doi: 10.1109/OCEANSAP.2006.4393978.

Clarke K R and Warwick R M 2001 Change in Marine Communities: An Approach to Statistical Analysis and Interpretation, 2nd edn, PRIMER-E, Plymouth, UK, Chapter 7, pp. 3-4.

Corliss B H and Fois E 1990 Morphotype analysis of deep-sea benthic foraminifera from the northwest Gulf of Mexico; Palaios 5 589-605.

Cullen J L 1981 Microfossil evidence for changing salinity patterns in the Bay of Bengal over the last 20,000 years; Paleogeogr. Paleoclimatol. Paleoecol. 35 315-356.

Cullen J L and Duplessy J C 1979 Changes in monsoonal circulation over the last ice-age cycle: Microfossil evidence from the Bay of Bengal; Geol. Soc. Am. Abstr. Prog. 11408.

den Dulk M, Reichart G J, Memon G M, Roelofs E M P, Zachariasse W J and van der Zwaan G J 1998 Benthic foraminiferal response to variations in surface water productivity and oxygenation in the northern Arabian Sea; Mar. Micropaleontol. 35 43-66.

Diaz R J and Rosenberg R 2008 Spreading dead zones and consequences for marine ecosystems; Science 321 926-929, doi: 10.1126/science.1156401.

Duijnstee I, De Lugt I, Vonk Nordegraaf H and Van Der Zwaan B 2004 Temporal variability of foraminiferal densities in the northern Adriatic Sea; Mar. Micropaleontol. 50 125-148, doi: 10.1016/S0377-8398(03)00069-0.

Duplessy J C 1982 Glacial to interglacial contrasts in the northern Indian Ocean; Nature 295 494-498.

Durand F F, Papa A and Rahman Bala S K 2011 Impact of Ganges-Brahmaputra interannual discharge variations on Bay of Bengal salinity and temperature during 1992-1999 period; J. Earth Syst. Sci. 120 859-872.

Fontanier C, Jorissen F J, Licari L, Alexandre A, Anschutz $\mathrm{P}$ and Carbonel P 2002 Live benthic foraminiferal faunas from the Bay of Biscay: Faunal density, composition, and microhabitats; Deep-Sea Res. 49 751-785, doi: 10013/epic.15528.d001.

Fontanier C, Jorissen F J, Lansard B, Mouret A, Buscail R, Schmidt S, Kerhervé P, Buron F, Zaragosi S, Hunault G, Ernoult E, Artero C, Anschutz P and Rabouille C 2008 Live foraminifera from the open slope between Grand Rhône and Petit Rhône Canyons (Gulf of Lions, NW Mediterranean); Deep-Sea Res. 55 1532-1553, doi: 10.1016/j.dsr.2008.07.003.

Ghosh B K 1966 Asterorotalia trispinosa (Thalmann), a spinose rotalid form Digha Beach, southeastern Bengal; Contr. Cushman Found. Foraminiferal Res. 17 104-108.

Ghosh S K and Bhattacharjee D 1993 Depositional events interpreted from Holocene records in the sediment cores off Paradeep, Bay of Bengal; Indian Minerals 47 293-304.

Glock N, Schonfeld J, Eisenhauer A, Hensen C, Mallon J and Sommer S 2013 The role of benthic foraminifera in the benthic nitrogen cycle of the Peruvian oxygen minimum zone; Biogeosci. 10 4767-4783, doi: 10.5194/bg-10-4767-2013.

Goineau A, Fontanier C, Jorissen F J, Lansard B, Buscail R, Mouret A, Kerherve P, Zaragosi S, Ernoult E, Artero C, Anschutz P, Metzger E and Rabouille C 2011 Live (stained) benthic foraminifera from the Rhone Prodelta (Gulf of Lion, NW Mediterranean): Environmental controls on a river-dominated shelf; J. Sea Res. 65 58-75, doi: 10.1016/j.seares.2010.07.007.

Goineau A, Fontanier C, Jorissen F, Buscail R, Kerherve P, Cathalot C, Prusk A, Lantoine M F, Bourgeois S, Metzger E, Legrand E and Rabouille C 2012 Temporal variability of live (stained) benthic foraminiferal faunas in a riverdominated shelf - Faunal response to rapid changes of the river influence (Rhone prodelta, NW Mediterranean); Biogeosci. 9 1367-1388, doi: 10.5194/bg-9-1367-2012.

Gomes H R, Goes J I and Saino T 2000 Influence of physical processes and freshwater discharge on the seasonality of phytoplankton regime in the Bay of Bengal; Cont. Shelf Res. 20 313-330, doi: 10.1016/S0278-4343(99)00072-2.

Gooday A J 1993 Deep-sea benthic foraminiferal species which exploit phytodetritus: Characteristic features and controls on distribution; Mar. Micropaleontol. 22 187205.

Gooday A J 2003 Benthic foraminifera (Protista) as tools in deep-water palaeoceanography: Environmental influences on faunal characteristics; Adv. Mar. Biol. 46 3-90.

Gooday A J and Rathburn A E 1999 Temporal variability in living deep-sea benthic foraminifera: A review; Earth Sci. Rev. 46 187-212.

Gooday A J, Levin L A, Aranda da Silva A, Bett B J, Cowie G, Dissard D, Gage J D, Hughes D J, Jeffreys R, Lamont P A, Larkin K E, Murty S J, Schumacher S, Whitcraft C and Woulds C 2009 Faunal responses to oxygen gradients on the Pakistan margin: A comparison of foraminiferans, macrofauna and megafauna; Deep-Sea Res. II 56 488502, doi: 10.1016/j.dsr2.2008.10.003.

Hayward B W and Hollis C J 1994 Brackish foraminifera in New Zealand: A taxonomic and ecologic review; Micropaleontol. 40 185-222. 
Hedges J I, Keil R G and Benner R 1997 What happens to terrestrial organic matter in the ocean? Org. Geochem. 27 195-212.

Islam S N and Gnauck A 2008 Mangrove wetland ecosystems in Ganges-Brahmaputra delta in Bangladesh; Front. Earth Sci. China 2 439-448, doi: 10.1007/s11707-0080049-2.

Jannink N T, Zachariasse W J and Van der Zwaan G J 1998 Living (Rose Bengal stained) benthic foraminifera from the Pakistan continental margin (northern Arabian Sea); Deep-Sea Res. I 45 1483-1513, doi: 10.1016/S0967-0637(98)00027-2.

Jayaraju N and Reddy K R 1997 Effect of river discharge on test morphology of benthic foraminifera, south east coast of India; J. Geol. Soc. India 50 435-439.

Jorissen F J 1999 Benthic foraminifera microhabitats below the sediment-water interface; In: Modern Foraminifera (ed.) Gupta B K S, Kluwer Academic Publishers, pp. 161-179.

Jorissen F J, Barmawidjaja B M, Puskaric S and van der Zwaan G J 1992 Vertical distribution of benthic foraminifera in the northern Adriatic Sea: The relation with the organic flux; Mar. Micropaleontol. 19 131-146.

Jorissen F J, de Stigter H C and Widmark J G V 1995 A conceptual model explaining benthic foraminiferal microhabitats; Mar. Micropaleontol. 26 3-15.

Jorissen F J, Fontanier C and Thomas E 2007 Paleoceanographical proxies based on deep-sea benthic foraminiferal assemblage characteristics; In: Proxies in Late Cenozoic Paleoceanography: Pt. 2: Biological tracers and biomarkers (eds) Hillaire-Marcel C and de Vernal A, Elsevier, pp. 263-326.

Kemp W M and Boynton W R 1992 Benthic-pelagic interactions: Nutrient and oxygen dynamics; In: Oxygen dynamics in the Chesapeake Bay - A synthesis of recent research (eds) Smith D E, Leffler M and Mackiernan G, OMaryland Sea Grant College, Maryland, pp. 149-222.

Khare N, Chaturvedi S K and Mazumder A 2007 An overview of foraminiferal studies in near shore regions off eastern coast of India, and Andaman and Nicobar Islands; Indian J. Mar. Sci 36 288-300.

Kitazato H, Shirayamab Y, Nakatsukac T, Fujiwaraa S, Shimanagad M, Katoe Y, Okadae Y, Kandaa J, Yamaokaa A, Masuzawaf T and Suzuki K 2000 Seasonal phytodetritus deposition and responses of bathyal benthic foraminiferal populations in Sagami Bay, Japan: Preliminary results from 'Project Sagami 1996-1999'; Mar. Micropaleontol. $40135-149$.

Lohrenz S E, Fahnenstiel G L, Redalje D G, Lang G A, Chen $\mathrm{X}$ and Dagg M J 1997 Variations in primary production of northern Gulf of Mexico continental shelf waters linked to nutrient inputs from the Mississippi River; Mar. Ecol. Prog. Ser. 155 45-54.

Mackensen A and Hald M 1988 Cassidulina teretis Tappan and C. laevigata d'Orbigny: Their modern and late Quaternary distribution in northern seas; J. Foram. Res. 18 16-24.

Mackensen A, Sejrup H P and Jansen E 1985 The distribution of living benthic foraminifera on the continental margin and rise off southwest Norway; Mar. Micropaleontol. 9 275-306.

Mazumder A and Nigam R 2014 Bathymetric preference of four major genera of rectilinear benthic foraminifera within oxygen minimum zone in Arabian Sea off central west coast of India; J. Earth Syst. Sci. 123 633-639.

Milliman J D and Meade R H 1983 World-wide delivery of river sediment to the oceans; J. Geol. 91 1-21.

Mojtahid M, Jorissen F, Lansard B, Fontanier C, Bombled B and Rabouille C 2009 Spatial distribution of live benthic foraminifera in the Rhône prodelta: Faunal response to a continental-marine organic matter gradient; Mar. Micropaleontol. 70 177-200, doi: 10.1016/ j.marmicro.2008.12.006.

Mojtahid M, Jorissen F, Lansard B and Fontanier C 2010 Microhabitat selection of benthic foraminifera in sediments off the Rhône River mouth (NW Mediterranean); J. Foram. Res. 40 231-246, doi: 10.2113/gsjfr.40.3.231.

Moodley L, van der Zwaan G J, Herman P M J, Kempers L and van Breugel P 1997 Differential response of benthic meiofauna to anoxia with special reference to Foraminifera (Protista: Sarcodina); Mar. Ecol. Prog. Ser. 158 $151-163$.

Murray J W 1991 Ecology and Palaeoecology of Benthic Foraminifera; Longman, Harlow, Essex, pp. 288, 289.

Murray J W 2006 Ecology and Applications of Benthic Foraminifera; Cambridge University Press, 426p.

Murray J W and Alve E 2011 The distribution of agglutinated foraminifera in NW European seas: Baseline data for the interpretation of fossil assemblages; Palaeontol. Elect. 14 14A:41p, palaeo-electronica.org/2011_2/248/ index.html.

Murray J W, Alve E and Cundy A 2003 The origin of modern agglutinated foraminiferal assemblages: Evidence from a stratified fjord; Estuar. Coast. Shelf Sci. 58 677697, doi: 10.1016/S0272-7714(03)00179-3.

Nagy J, Reolid M and Rodríguez-Tovar F J 2009 Foraminiferal morphogroups in dysoxic shelf deposits from the Jurassic of Spitsbergen; Polar Res. 28 214-221, doi: 10.1111/j.1751-8369.2009.00112.x.

Naqvi S W A, De Sousa S N, Fondekar S P and Reddy C V G 1979 Distribution of dissolved oxygen in the western Bay of Bengal; Mahasagar 12 25-34.

Naqvi S W A, Naik H and Narvekar P V 2003 The Arabian Sea; In: Biogeochemistry of Marine Systems (eds) Black K and Shimmield G B, Oxford UK, pp. 157-207.

Neira C, Sellanes J, Levin L A and Arntz W E 2001 Meiofaunal distributions on the Peru margin: Relationship to oxygen and organic matter availability; Deep-Sea Res. I $482453-2472$.

Nigam R 1993 Foraminifera and changing pattern of monsoon rainfall; Curr. Sci. 64 935-937.

Nigam R and Khare N 1994 Effect of river discharge on the morphology of benthic foraminiferal test; J. Geol. Soc. India 43 457-463.

Nigam R and Khare N 1999 Spatial and temporal distribution of foraminifera in sediments off the central west coast of India and use of their test morphologies for the reconstruction of paleomonsoonal precipitation; Micropaleontol. 45 285-303.

Nigam R, Khare N and Borole D V 1992 Can benthic foraminiferal morpho-groups be used as indicators of paleomonsoonal precipitation; Estuar. Coast. Shelf Sci. 34 533-542.

Nigam R, Khare N and Nair R R 1995 Foraminiferal evidences for 77-year cycles of draught in India and its possible modulation by the Gleissberg cycle; J. Coast. Res. 11 1099-1107.

Nigam R, Khare N and Mayenkar D N 2000 Can bathymetry be a discriminatory factor for the distribution of benthic foraminiferal morpho-groups in modern marine sediments? ONGC Bull. 37 47-51.

Nigam R, Saraswat R and Kurtarkar S R 2006 Laboratory experiment to study effect of salinity variations on benthic foraminiferal species - Pararotalia nipponica (Asano); J. Geol. Soc. India 67 41-46.

Nigam R, Mazumder A, Henriques P J and Saraswat R 2007 Benthic foraminifera as proxy for oxygen depleted conditions off the central west coast of India; J. Geol. Soc. India 70 1047-1054. 
Nigam R, Kurtarkar S R, Saraswat R, Linshy V N and Rana S S 2008 Response of benthic foraminifera Rosalina leei to different temperature and salinity, under laboratory culture experiment; J. Mar. Biol. Assoc. UK 88 699-704, doi: 10.1017/S0025315408001197.

Nigam R, Prasad V, Mazumder A, Garg R, Saraswat R and Henriques P J 2009 Late Holocene changes in hypoxia off the west coast of India Micropalaeontological evidences; Curr. Sci. 96 708-713.

Panchang R and Nigam R 2012 High resolution climatic records of the past $\sim 489$ years from Central Asia as derived from benthic foraminiferal species, Asterorotalia trispinosa; Mar. Geol. 307-310 88-104, doi: 10.1016/j.margeo.2012.01.006.

Panchang R, Nigam R, Raviprasad G V, Rajagopalan G, Ray D K and Yi Hla U Ko 2008 Relict faunal testimony for sea-level fluctuations off Myanmar (Burma); J. Palaeontol. Soc. India 53 185-195.

Prasanna Kumar S, Narvekar J, Nuncio M, Kumar A, Ramaiah N, Sardessai S, Gauns M, Fernandes V and Paul J 2010 Is the biological productivity in the Bay of Bengal light limited? Curr. Sci. 98 1331-1339.

Qasim S Z 1977 Biological productivity of the Indian Ocean; Indian J. Mar. Sci. 6 122-137.

Ramette A 2007 Multivariate analyses in microbial ecology; FEMS Microbiol. Ecol. 62 142-160.

Rana S S and Nigam R 2009 Cyclicity in late Holocene monsoonal changes from the western Bay of Bengal: Foraminiferal approach; J. Paleontol. Soc. India $\mathbf{5 4}$ $165-170$.

Rana S S, Nigam R and Panchang R 2007 Relict benthic foraminifera in surface sediments off central east coast of India as indicator of sea level changes; Indian J. Mar. Sci. 36 355-360.

Rao C K, Naqvi S W A, Kumar M D, Varaprasad S J D, Jayakumar D A, George M D and Singbal S Y S 1994 Hydrochemistry of the Bay of Bengal: Possible reasons for a different water-column cycling of carbon and nitrogen from the Arabian Sea; Mar. Chem. 47 279-290.

Rao R N, Jayaprakash M and Velmurugan P M 2013 The ecology of Asterorotalia trispinosa - New insights from Muthupet Lagoon, southeast coast of India; J. Foramin. Res. 43 14-20, doi: 10.2113/gsjfr.43.1.14.

Saraswat R, Nigam R and Barreto L 2005 Paleoceanographic implications of abundance and mean proloculus diameter of benthic foraminiferal species Epistominella exigua in sub-surface sediments from distal Bay of Bengal Fan; J. Earth Syst. Sci. 114 453-458.

Sarin M M, Krishnaswami S, Dilli K, Somayajulu B L K and Moore W S 1989 Major ion chemistry of the GangaBrahmaputra river system: Weathering processes and fluxes to the Bay of Bengal; Geochim. Cosmochim. Acta 53 997-1009.
Sarma V V S S, Krishna M S, Viswanadham R, Rao G D, Rao V D, Sridevi B, Kumar B S K, Prasad V R, Subbaiah ChV, Acharyya T and Bandopadhyay D 2013 Intensified oxygen minimum zone on the western shelf of Bay of Bengal during summer monsoon: Influence of river discharge; J. Oceanogr. 69 45-55, doi: 10.1007/s10872-012-0156-2.

Schlitzer R 2015 Ocean Data View; http://odv.awi.de.

Schumacher S, Jorissen F J, Dissard D, Larkin K E and Gooday A J 2007 Live (Rose Bengal stained) and dead benthic foraminifera from the oxygen minimum zone of the Pakistan continental margin (Arabian Sea); Mar. Micropaleontol. 62 45-73.

Sen Gupta B K and Machain-Castillo M L 1993 Benthic foraminifera in oxygen-poor habitats; Mar. Micropaleontol. $203-4$.

Sengupta D, Bharath Raj G N and Shenoi S S C 2006 Surface freshwater from Bay of Bengal runoff and Indonesian throughflow in the tropical Indian Ocean; Geophys. Res. Lett. 33 L22609, doi: 10.1029/2006GL027573.

Setty M G A P and Nigam R 1982 Foraminiferal assemblages and organic carbon relationship in benthic marine ecosystem of western Indian continental shelf; J. Mar. Sci. 11 225-232.

Severin K P 1983 Test morphology of benthic foraminifera as a discriminator of biofacies; Mar. Micropalaeontol. 8 $65-76$.

Shetye S R 1993 Movement and implications of GangesBrahmaputra run off on entering the Bay of Bengal; Curr. Sci. 64 32-38.

Shetye S R, Shenoi S S C, Gouveia A D, Michael G S, Sundar D and Nampoothiri G 1991 Wind-driven coastal upwelling along the western boundary of the Bay of Bengal during the southwest monsoon; Cont. Shelf Res. 11 1397-1408.

Sturdivant S K, Díaz R J and Cutter G R 2012 Bioturbation in a declining oxygen environment, in situ observations from Wormcam; PLoS One 7 e34539, doi: 10.1371/journal.pone.0034539.

ter Braak C J F 1986 Canonical correspondence analysis: A new eigenvector technique for multivariate direct gradient analysis; Ecology 67 1167-1179.

Unger D, Ittekkot V, Schafer P, Tiemann J and Reschke S 2003 Seasonality and inter-annual variability of particle fluxes to the deep Bay of Bengal: Influence of riverine input and oceano-graphic processes; Deep-Sea Res. II 50 897-923.

Varkey M J, Murty V S N and Suryanarayana A 1996 Physical oceanography of the Bay of Bengal and Andaman Sea; Oceanogr. Mar. Biol. Ann. Rev. 34 1-70.

Wahyudi C and Minagawa M 1997 Response of benthic foraminifera to organic carbon accumulation rates in the Okinawa trough; J. Oceanogr. 53 411-420.

Wyrtki K 1971 Oceanographic Atlas of the International Indian Ocean Expedition; Natl. Sci. Found. Washington DC, pp 53t. 